\title{
Penerapan Model Strategi Bisnis Pada Koperasi Syariah
}

\author{
Sofiyanurriyanti \\ Jurusan Teknik Industri, Fakultas Teknik, Sekolah Tinggi Teknik Qomaruddin Gresik \\ Alamat Jalan Raya No. 01 Bungah Gresik, Telp. (031)-3943999, Fax. (031) 3943999 \\ Surel : sofiyanurriyanti20@gmail.com
}

\begin{abstract}
Koperasi BMT Syariah East Java is one of sharia-based cooperatives located in the area of Gresik, East Java. BMT cooperatives encountered many obstacles in society such as low awareness of the public in cooperatives, negative impression of the cooperative BMT, the level of customer confidence in the institution to be low, the limitations of market coverage and others. The matrices used in this study are IFE (Internal Factor Evaluation), EFE (External Factor Evaluation), CPM (Competitive Profile Matrix), SWOT, SPACE (Strategic Position and Action Evaluation), BCG (Boston Consulting), IE Matrix (Internal-External), Grand Strategy Matrix, QSPM (Quantitative Strategic Planning Matrix) and Architecture Strategy. The results of this study are several alternative strategies such as Strategy 3 (S3), which is to improve the image of sharia cooperative BMT, Strategy 1 (S1) Increase participation, Strategy 6 (S6) establish partnership relationship with financial institution, Strategy 10 (S10) Product range and strategy 2 (S2) Expand the market. The next stage is the strategy architecture that is the stage toward the development stage, the stage of business development activities and the stage of maintaining the business. Strategy architecture stage is done by making short, medium and long term plan.
\end{abstract}

Keyword: Coorporation BMT, Management Strategy

\begin{abstract}
Abstrak
Koperasi BMT Syariah Jawa Timur merupakan salah satu koperasi yang pengelolahannya berbasis syariah terletak didaerah Gresik, Jawa Timur. Koperasi BMT menemui banyak kendala di masyarakat seperti rendahnya kesadaran masyarakat dalam berkoperasi, kesan negatif dari koperasi BMT, tingkat kepercayaan nasabah terhadap lembaga menjadi rendah, keterbatasan cakupan pasar dan lain-lain. Matriks-matriks yang digunakan pada penelitian ini adalah IFE (Internal Factor Evaluation), EFE (External Factor Evaluation), CPM (Competitive Profile Matriks), SWOT, SPACE (Strategic Position and Action Evaluation), BCG (Boston Consulting), Matriks IE (Internal-External), Grand Strategy Matrix, QSPM (Quantitative Strategic Planning Matrix) dan Arsitektur Strategy. Hasil penelitian ini adalah beberapa alternatif strategi di antaranya adalah Strategi 3 (S3) yaitu memperbaiki citra koperasi syariah BMT, Strategi 1 (S1) Meningkatkan partisipasi, Strategi 6 (S6) menjalin hubungan kemitraan dengan lembaga keuangan, Strategi 10 (S10) yaitu memperkenalkan macam-macam produk dan strategi 2 (S2) Memperluas pasar. Tahap selanjutnya adalah arsitektur strategi yang merupakan tahap menuju tahap pengembangan, tahap kegiatan pengembangan bisnis dan tahap mempertahankan usaha. Tahap arsitektur strategi dilakukan dengan membuat rencana jangka pendek, menengah dan panjang.
\end{abstract}

Kata Kunci : Koperasi BMT, Manajemen Strategi

\section{Pendahuluan}

Baitul Maal wat Tanwil (BMT) merupakan lembaga keuangan dengan konsep berbasis syariah yang lahir sebagai pilihan dengan menggabungkan konsep maal dan tamwil dalam satu kegiatan lembaga. Konsep maal lahir dan menjadi bagian dari 
kehidupan masyarakat muslim dalam hal menyalurkan dana seperti zakat, infaq, dan shadaqah. Sedangkan untuk konsep tamwil merupakan lahir dalam kegiatan bisnis untuk mendapatkan keuntungan dengan sektor masyarakat menengah ke bawah (mikro usaha). Koperasi BMT Syariah Jawa Timur merupakan salah satu koperasi yang pengelolaannya berbasis syariah.

Koperasi BMT berdiri berawal dari perkumpulan masyarakat biasa yang mempunyai ide kelompok usaha bersama yang disebut KUBE. Koperasi BMT Syariah Jawa Timur awal mula didirikan pada tahun 2004. Perkembangan lembaga keuangan mikro berbasis syariah dalam bentuk koperasi jasa keuangan syariah (KJKS), Koperasi Simpan Pinjam Syariah (KSPS) atau Unit Simpan Pinjam Syariah (USPS) biasanya menggunakan nama Baitul Mal Wat Tamwil (BMT) [1]. Banyak kendala di masyarakat seperti kesadaran masyarakat dalam berkoperasi, kesan negatif dari koperasi BMT. Mengatasi permasalahan tersebut, makalah ini menjelaskan perancangan strategi bisnis yang akan membantu menyelesaikan permasalahan tersebut [2]. Osterwalder and Pigneur [3] menjelaskan bahwa aspek lingkungan yang memengaruhi bisnis model antara lain market issues, market segments, needs and demands, switching cost, dan revenue attractiveness. Kelemahan yang dihadapi industri BMT seperti ketersediaan informasi tentang profil dan kinerja BMT yang perlu diperbaiki dengan cara melakukan survei di daerah yang menjadi pusat kegiatan BMT oleh karena itu, perbaikan yang perlu dilakukan dengan pengoptimalan peran Asosiasi BMT dan Agen agen dari BMT [4]. Kelebihan dari koperasi dan BMT mempunyai tujuan yaitu untuk menyejahterakan anggotanya dan masyarakat pada umumnya tidak memandang beberapa besar modal yang ditanamkan oleh anggotanya melainkan segi partisipasinya sangat menjunjung tinggi nilai nilai kemanusiaan didalam prakteknya [5].

Beberapa penelitian mengenai penerapan proses bisnis pada koperasi BMT masih dipublikasikan terbatas seperti yang dilakukan oleh Harmoyo [1]. Tujuan penelitiannya menganalisis faktor eksternal dan faktor internal KJKS BMT Syariah Sejahtera dengan cara menyusun rencana kebijakan perekrutan dan promosi karyawan yang efektif. Berdasarkan uraian di atas, maka penelitian ini akan dilakukan menguraikan tahapan merumuskan strategi bisnis pada Koperasi BMT Syariah Jawa Timur. Penelitian ini khususnya perumusan strategi bisnis pada Koperasi BMT Syariah Jawa Timur adalah membuat usulan rencana implementasi strategi alternatif dalam menghadapi persaingan bisnis yang akan dilakukan dan membuat rancangan arsitektur strategi.

\section{Metode Penelitian}

Tahap awal pada penelitian adalah dilakukan 2 cara yaitu eksploratif dan deskriptif. Studi eksploratif dilakukan dengan cara wawancara. Sedangkan studi desktiptif dilakukan dengan membuat gambaran objek maupun subjek dalam penelitian yang berdasarkan pada fakta-fakta yang ada.

Alat pengumpulan data pada penelitian adalah dengan menggunakan kuesioner dan wawancara. Data yang diperoleh kemudian diolah menggunakan pendekatan model David [6]. Model strategi tersebut mempunyai tiga tahapan yaitu:

a. Tahap Masukan

Pada tahap ini terdapat dua matriks yaitu matriks Internal Factor Analysis (IFAS), Eksternal Factor Analysis (EFAS) dan matriks Competitive Profile Matrix (CPM). Matriks ini akan menjadi data input tahap tahap pencocokan.

b. Tahap Pencocokan 
Tahap ini merupakan tahap kedua setelah tahap input. Pada tahap ini terdapat beberapa matriks di antaranya adalah Strengths Weaknesses Opportunities and Threats (SWOT), SPACE Matriks, Boston Consulting Group (BCG), Internal External (IE) matriks, dan Grand Strategy Matrix. Lima matriks tersebut akan menghasilkan alternatif strategi yang nantinya akan dicocokkan kemudian diolah pada tahap pengambilan kesimpulan.

c. Tahap Pengambilan Keputusan

Pada tahap ini terdapat satu matriks yaitu Quantitative Strategic Planning Matrix (QSPM). Matriks ini digunakan menentukan strategi alternatif mana yang menjadi prioritas utama.

\section{Hasil dan Pembahasan}

Tahap-tahapan yang akan dilakukan pada pengolahan data dan pembahasan ini terdiri dari faktor internal dan faktor eksternal, data tersebut nantinya akan melewati beberapa tahapan antara lain :
a. Tahap Input (Masukan)
b. Tahap Pencocokan
c. Tahap Pengambilan Keputusan
d. Tahap Pengembangan

\subsection{Tahap Input}

\subsubsection{Internal Factor Analysis (IFAS)}

Pada faktor internal untuk menetukan nilai IFAS pada setiap faktornya kekuatan dan kelemahan dapat dihitung dari nilai bobot dan rating, yang ditunjukkan pada Tabel 1. Berdasarkan Tabel 1 diketahui bahwa nilai bobot tertinggi adalah 0.104 yaitu transparansi program kerja, sedangkan untuk nilai bobot yang paling rendah adalah 0.036 yaitu tingkat kedisiplinan tenaga kerja. Faktor kelemahan (weakness) mempunyai nilai 1.26 lebih tinggi dari pada yaitu 1.19 yang berarti koperasi BMT ini lebih banyak memiliki kelemahan daripada kekuatan.

\subsubsection{Eksternal Factor Analysis}

Pada faktor internal untuk menetukan nilai IFAS pada setiap faktornya kekuatan dan kelemahan dapat dihitung dari nilai bobot dan rating, yang ditunjukkan pada Tabel 2. Berdasarkan Tabel 2 diketahui bahwa nilai bobot tertinggi adalah 0.216 yaitu kebijakan pemerintahan daerah, sedangkan untuk nilai bobot yang paling rendah adalah 0.041 yaitu pertumbuhan ekonomi. Faktor ancaman (thread mempunyai nilai 1.61 lebih tinggi dari pada peluang (opportunities) yaitu 1.52 yang berarti koperasi BMT ini lebih banyak memiliki ancaman daripada peluang.

\subsubsection{Matriks Competitive Profile Matrix (CPM)}

Competitive Profile Matriks digunakan untuk mengetahui posisi relatif perusahaan dibandingkan dengan perusahaan pesaing [6]. Posisi relatif perusahaan dibandingkan dengan perusahaan pesaing dapat dilihat pada Tabel 3. 
Tabel 1 IFAS (Internal Factor Analysis)

\begin{tabular}{clccc}
\hline \multicolumn{5}{c}{ Faktor Strategi Internal } \\
\hline No & \multicolumn{1}{c}{ KEKUATAN (Strenght) } & Bobot & Rating & Bobot * Rating \\
\hline 1 & Ketrampilan yang dimiliki oleh pekerja & 0.049 & 2 & 0.097 \\
\hline 2 & Tingkat pendidikan pekerja & 0.061 & 3 & 0.183 \\
\hline 3 & Pelatihan dan pembinaan tenaga kerja & 0.090 & 1 & 0.090 \\
\hline 4 & Transparansi program kerja & 0.104 & 2 & 0.208 \\
\hline 5 & Bentuk promosi & 0.087 & 2 & 0.175 \\
\hline 6 & Lokasi yang strategis & 0.077 & 2 & 0.153 \\
\hline 7 & Prosedur pembiayaan & 0.078 & 2 & 0.156 \\
\hline 8 & Jenis Produk & 0.065 & 2 & 0.131 \\
\hline \multicolumn{2}{c}{ Sub Total Kekuatan (Strenght) } & & 1.19 \\
\hline
\end{tabular}

Faktor Strategi Internal

\begin{tabular}{clccc} 
No & \multicolumn{1}{c}{ KELEMAHAN (Weakness) } & Bobot & Rating & Bobot * Rating \\
1 & Pengawasan dan kapasitas SDM & 0.040 & 4 & 0.159 \\
\hline 2 & Tingkat kedisplinan tenaga kerja & 0.036 & 4 & 0.143 \\
\hline 3 & Perputaran piutang dagang & 0.040 & 4 & 0.160 \\
\hline 4 & Penggunaan teknologi (IT) & 0.075 & 4 & 0.298 \\
\hline 5 & Mutu pelayanan & 0.066 & 4 & 0.264 \\
\hline 6 & Sistem pengawasan mutu & 0.059 & 4 & 0.238 \\
\hline 7 & Modal usaha yang memadai & 0.073 & 3 & 0.218 \\
\hline Sub Total Kelemahan (Weakness) & & & 1.26 \\
\hline \multicolumn{2}{r}{ TOTAL IFAS } & 1 & & 2.46 \\
\hline
\end{tabular}

Tabel 2 EFAS (Eksternal Factor Analysis)

\begin{tabular}{|c|c|c|c|c|}
\hline \multicolumn{5}{|c|}{ Faktor Strategi Eksternal } \\
\hline & PELUANG (Opportunities) & Bobot & Rating & Bobot * Rating \\
\hline 1 & Pinjaman modal dari bank & 0.147 & 2 & 0.294 \\
\hline 2 & Kebijakan pemerintahan daerah & 0.216 & 3 & 0.649 \\
\hline 3 & Status Lembaga & 0.116 & 3 & 0.348 \\
\hline 4 & Kerjasama dengan instansi & 0.057 & 4 & 0.227 \\
\hline & Sub Total Peluang (Opportunities) & & & 1.52 \\
\hline \multicolumn{5}{|c|}{ Faktor Strategi Eksternal } \\
\hline & ANCAMAN (Thread) & Bobot & Rating & Bobot * Rating \\
\hline 1 & Pertumbuhan ekonomi & 0.041 & 4 & 0.166 \\
\hline & Muncul keberadaan kompetitor & 0.046 & 4 & 0.186 \\
\hline 3 & Kepercayaan masyarakat terhadap koperasi & 0.079 & 4 & 0.315 \\
\hline 4 & Persaingan usaha dengan lembaga yang sama & 0.056 & 4 & 0.224 \\
\hline 5 & Tingkat inflasi dan nilai tukar & 0.117 & 3 & 0.352 \\
\hline 6 & Kemampuan ekonomi masyarakat sekitar & 0.124 & 3 & 0.371 \\
\hline & Sub Total Ancaman (Thread) & & & 1.61 \\
\hline & TOTAL EFAS & 1 & & 3.13 \\
\hline
\end{tabular}




\subsection{Tahap pencocokan}

\subsubsection{SWOT}

Menurut Rangkuti [7], matriks SWOT digunakan menyusun strategi organisasi atau perusahaan. Matriks ini menggambarkan bagaimana peluang dan ancaman eksternal yang dihadapi perusahaan dapat disesuaikan dengan kekuatan dan kelemahan yang dimilikinya. Matriks SWOT menunjukkan beberapa strategi alternatif, di antaranya adalah :

1. Meningkatkan kualitas pelayanan prima dan pengelolaan usaha sesuai prinsip syariah

2. Menjalin hubungan baik dengan pemerintahan dalam pembinaan dan pelatihan koperasi

3. Pengembangan layanan melalui peningkatan jumlah SDM

4. Memperluas pangsa pasar

5. Menjadikan masyarakat sebagai media promosi yang disekitar

6. Memanfaatkan kebijakan pemerintahan untuk pelatihan dan pembinaan dalam peningkatan kinerja pengurus anggota

7. Memberikan penyuluhan dan melibatkan anggota dalam program-program koperasi

8. Meningkatkan pelayanan terhadap anggota maupun non anggota

9. Menjalin komunikasi dengan pemerintahan terkait dengan kebijakan ekonomi

10. Optimalisasi pelayanan dan pembinaan usaha anggota untuk memotivasi loyalitas dan minat menabung anggota

11. Mengintensifkan pelatihan atau pendidikan anggota di bidang perkoperasian dan penerapan pola syariah

12. Pembinaan atau pendidikan anggota di bidang perkoperasian dan penerapan pola syariah

13. Menerapkan sistem reward and punishment untuk anggota dan pengurus

14. Menganalisis pengajuan kredit anggota

15. Membuat SOP yang diperlukan

16. Meningkatkan pencitraan koperasi melalui peningkatan pengawasan internal dan eksternal

17. Menjalin hubungan kemitraan atau kerja sama dengan lembaga keuangan yang sama

18. Memperkenalkan produk yang lebih baik sebagai respons terhadap penawaran baru dari pesaing

19. Meningkatkan partisipasi dan kesadaran anggota

20. Meningkatkan modal sendiri melalui simpanan anggota dan modal penyertaan anggota

21. Meningkatkan kualitas SDM yang handal dan tangguh

\subsubsection{Matriks SPACE}

Matriks SPACE digunakan memetakan kondisi perusahaan. Matriks SPACE menggunakan model diagram kartesius yang terdiri atas empat kuadran dengan skala ukuran yang sama [6]. Gambar 1 menunjukkan strategi yang digunakan adalah strategi competitive. Strategi tersebut menunjukkan perusahaan yang sedang berkompetisi secara fair pada industri yang tidak stabil. Perusahaan berfokus pada bagaimana meningkatkan hal-hal yang masih lemah (internal weakness) dan menghindari (external threats). Alternatif strategi competitive ini adalah strategi backward, foward, dan 
horizontal integration, market penetration, market development, product development dan joint venture.

Tabel 3 Matriks CPM (Competitive Profile Matrik)

\begin{tabular}{lccccc}
\hline \multirow{2}{*}{ Faktor Strategi } & \multirow{2}{*}{ Bobot } & \multicolumn{2}{c}{ Koperasi BMT } & \multicolumn{2}{c}{ Koperasi BMT } \\
\cline { 3 - 6 } & & Syariah Jawa Timur & \multicolumn{2}{c}{ Nurul Jannah } \\
\cline { 3 - 6 } & 0.141 & 3 & 0.424 & 3 & 0.424 \\
\hline Proporsi Mudhorobah & 0.146 & 2 & 0.293 & 4 & 0.586 \\
\hline Pangsa Pasar & 0.149 & 2 & 0.298 & 3 & 0.447 \\
\hline Sistem Manajemen & 0.178 & 3 & 0.535 & 3 & 0.535 \\
\hline Pelayanan Pelanggan & 0.186 & 2 & 0.372 & 3 & 0.558 \\
\hline Sistem Promosi/periklanan & 0.128 & 3 & 0.384 & 2 & 0.256 \\
\hline Varian Produk & 0.071 & 3 & 0.214 & 3 & 0.214 \\
\hline Posisi Keuangan & 0.8009 & & 2.519 & & 3.019 \\
\hline \multicolumn{1}{c}{ TOTAL } & & & & & Total \\
\hline
\end{tabular}

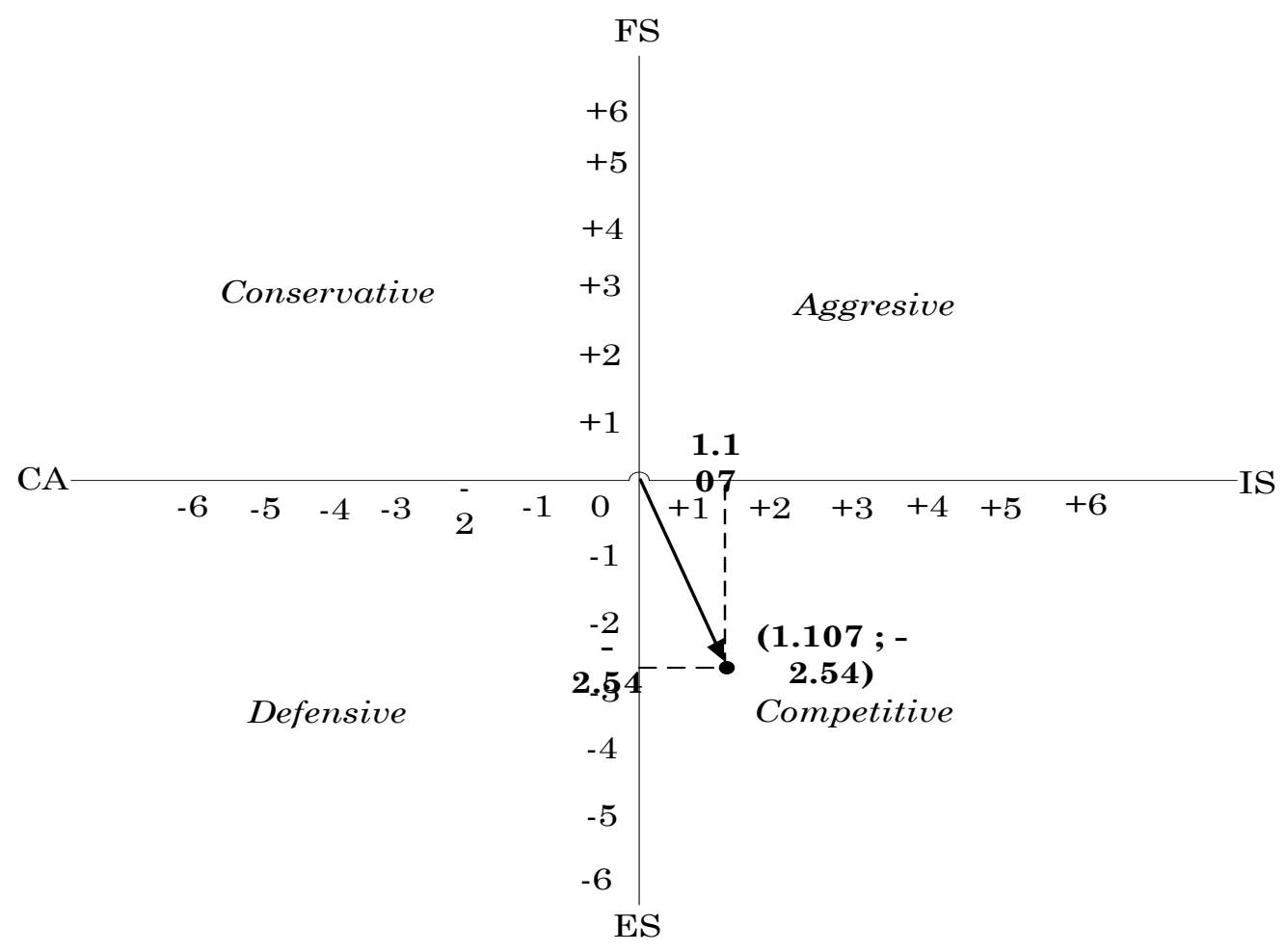

Gambar 1 Matriks SPACE (Strategy Position and Action)

\subsubsection{Matriks BCG}

Metode matriks BCG digunakan untuk mengetahui posisi tingkat pertumbuhan pasar pada koperasi BMT berdasarkan market share [6]. Berdasarkan Gambar 2 matriks BCG posisi dari Koperasi BMT Syariah Jawa Timur pada tahun 2010 dan 2011 
berada pada posisi dogs (anjing) yang terletak di kuadran IV. Matriks BCG tersebut menunjukkan bahwa posisi Koperasi BMT berada pada pangsa relatif rendah dan bersaing pada pasar industri yang pertumbuhannya lemah atau bahkan tidak ada pertumbuhanan, oleh karena itu berada pada posisi lemah baik eksternal maupun internal maka bisnis ini sring dilikuidasi atau didivestasi melalui strategi retrenchment yang terbaik untuk digunakan.

Sedangkan pada Koperasi BMT Nurul Jannah berada pada posisi stars (bintang) yang terletak di kuadran II yang menunjukkan bahwa posisi Koperasi BMT Nurul Jannah memperlihatkan bahwa perusahaan memiliki long run opportunities terbaik dalam hal pertumbuhan dan laba.

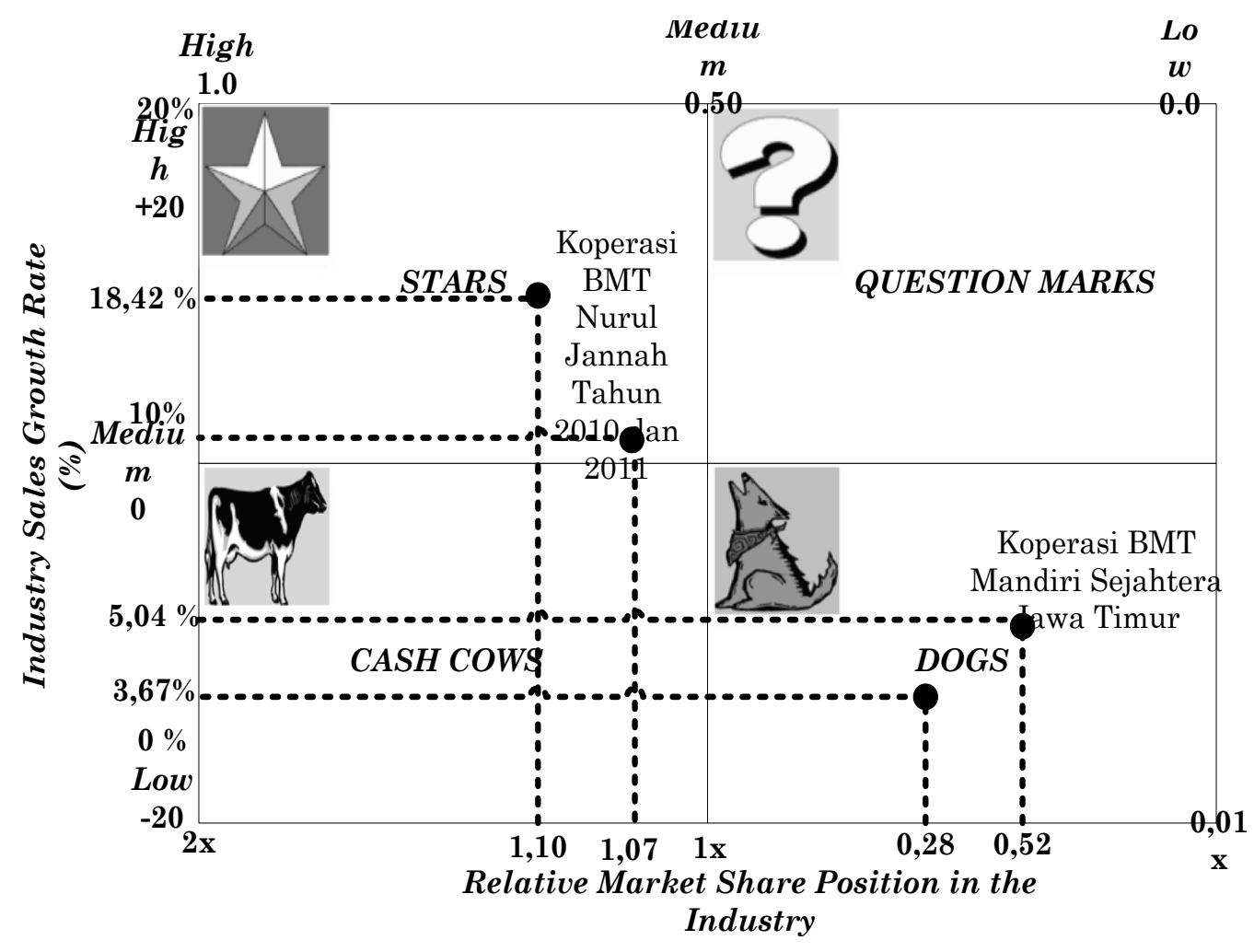

Gambar 2 Matriks BCG (Boston Consulting Group)

\subsubsection{Matriks IE (Internal-Eksternal)}

Matriks IE bermanfaat untuk memosisikan Koperasi BMT Syariah Jawa Timur ke dalam matriks yang terdiri atas 9 sel. Berdasarkan hasil posisi sel pada Gambar 3, diperoleh hasil total skor IFAS dan EFAS terletak diposisi sel II (warna abu-abu) dengan total skor pada IFAS sebesar 2,46 yang terletak disumbu X dan EFAS sebesar 3,13 yang terletak disumbu $\mathrm{Y}$. 


\subsubsection{Matriks Grand Strategy}

Matriks yang terakhir dari tahap pencocokan adalah grand strategy matriks. Pada matriks grand strategy telah menjadi alat populer bagi perumusan strategi alternatif [6].

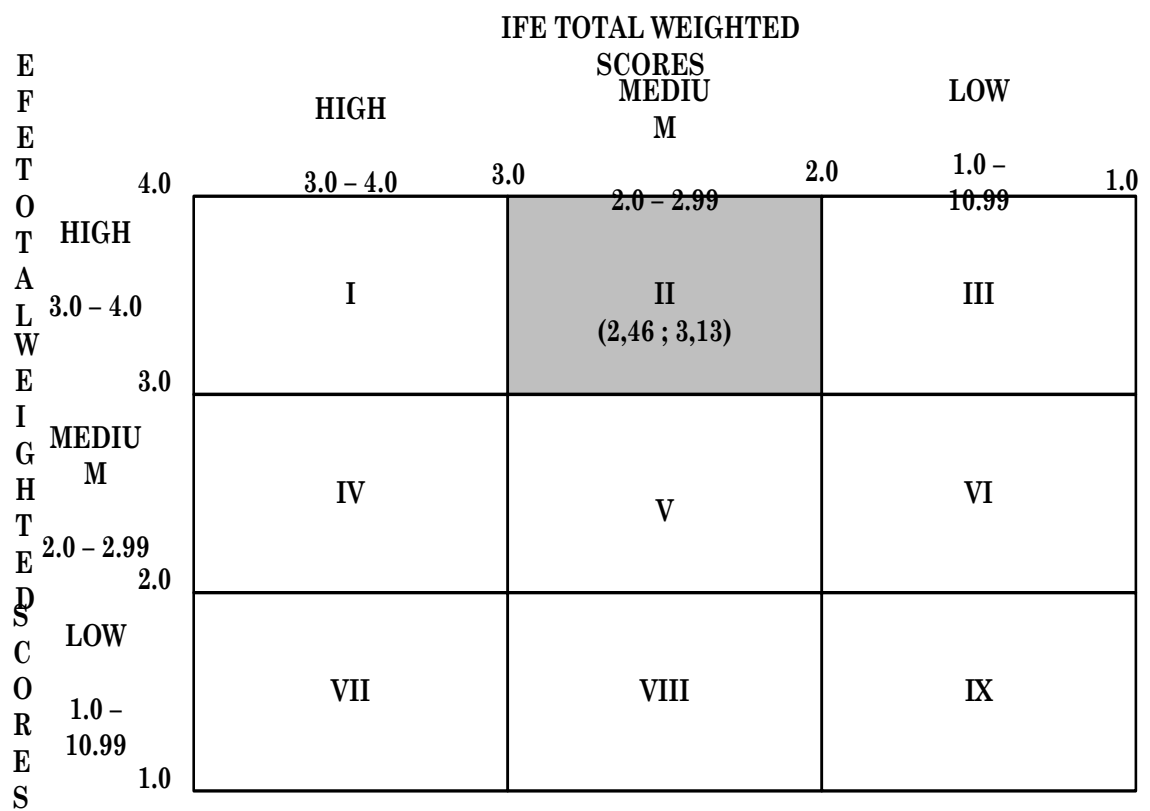

Gambar 3 Matriks IE (Internal-Eksternal)

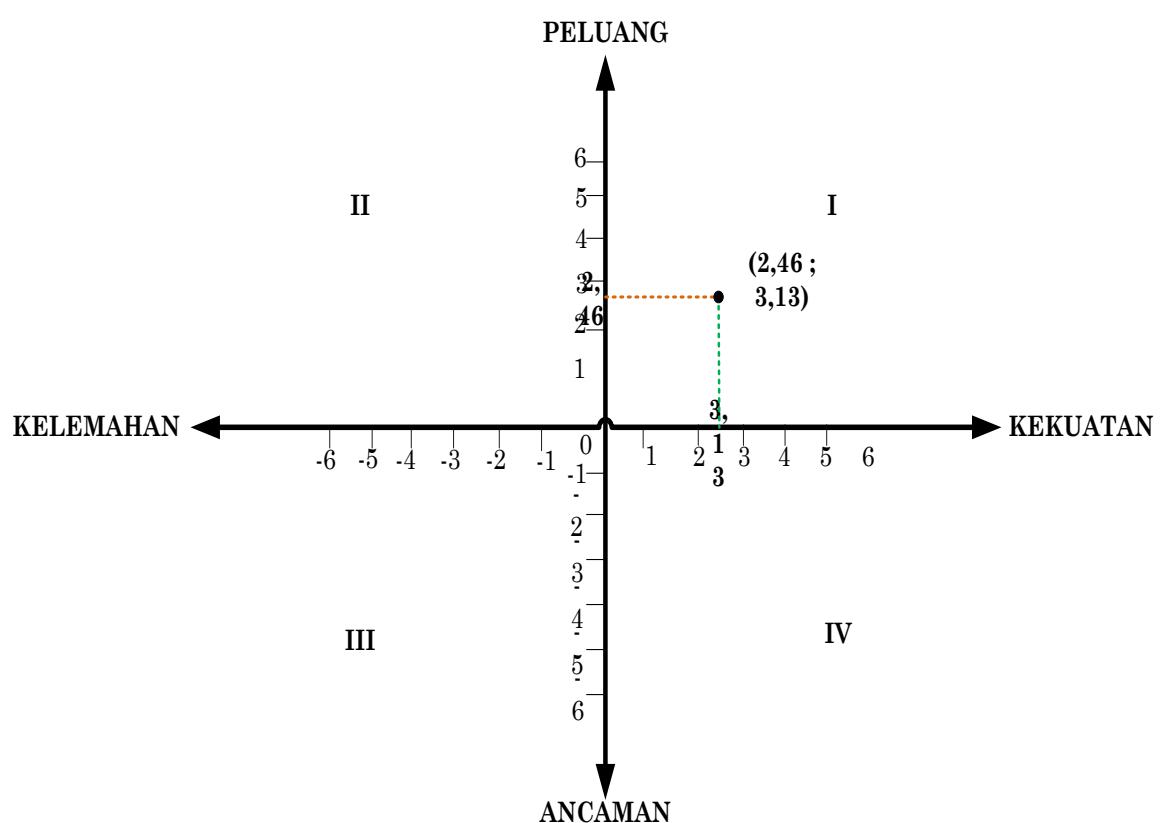

Gambar 4 Matriks Grand Strategy

Gambar 4 menunjukkan bahwa nilai IFAS sebesar 2,82 dan nilai EFAS sebesar 3,13 yang berada di kuadran I. Strategi yang dapat diterapkan di koperasi BMT ini adalah perkembangan pasar, penetrasi pasar, pengembangan produk, integrasi ke depan, integrasi ke belakang, integrasi horizontal, dan diversifikasi konsentris. 


\subsection{Tahap Pengambilan Keputusan}

QSPM merupakan alat rekomendasikan bagi ahli strategi untuk melakukan evaluasi pilihan strategi alternatif secara objektif, berdasarkan faktor internal dan eksternal yang telah diidentifikasi sebelumnya [6]. Matriks QSPM digunakan menentukan alternatif strategi mana yang di gunakan pada Koperasi BMT Mandiri Sejahtera Jawa Timur. Perhitungan QSOM dilakukan dengan mengalikan nilai bobot dari masing-masing faktor kunci dengan nilai daya tarik (attractiveness score) strategi yang disebut TAS (Total Attractiveness Score). Hasil perkalian tersebut kemudian dijumlah. Tabel 4 merupakan tabel yang mengurutkan nilai TAS mulai dari yang terbesar hingga terkecil.

\section{4 Proses Pengembangan}

Proses Perencanaan merupakan suatu rencana atau rencana-rencana dapat dilihat dari beberapa sisi penting yaitu dari sisi jangka waktu manfaat rencana serta dari sisi fungsinya, yaitu dari sisi strategis dan operasional [6]. Perencanaan dibuat dalam jangka pendek (1-2 tahun), jangka menengah (3-4 tahun) dan jangka panjang (5 tahun).

\section{A. Jangka pendek (1-2 tahun)}

Perencanaan jangka pendek dibuat dalam jangka waktu bulanan, kuartalan atau tengah tahunan. Perencanaan jangka pendek lebih konkret dan lebih rinci, lebih terukur dan sasaran yang harus dicapai lebih jelas, termasuk dalam hal penggunaan sumber daya, metode pelaksanaan, serta waktu mulai dan selesainya tiap-tiap kegiatan yang masuk dalam rencana tersebut [6].

1. Strategi 3 (S3) yaitu memperkenalkan macam-macam produk koperasi dikalangan masyarakat, melakukan penyuluhan dan melibatkan anggota dalam memperkenalkan produk-produk apa saja yang ada dikoperasi syariah, dan memberikan cara untuk bergabung dikoperasi syariah ini.

2. Strategi 1 (S1) yaitu meningkatkan kualitas sumber daya manusia yang handal dan tangguh (berkompeten), memberikan kinerja yang sangat selektif untuk memberikan yang terbaik, dengan memberikan sumber daya yang sudah profesional dalam bidang syariah yang sangat mengenal koperasi lebih jelas lagi.

3. Strategi 8 (S8) yaitu meningkatkan kualitas pelayanan dan pengelolaan pada usaha koperasi sesuai dengan prinsip syariah karena dengan peningkatan pelayanan kepada anggota maupun non anggota dapat dilakukan dengan memberikan pelayanan yang lebih cepat dan efisien ketika transaksi disetiap unit usaha, seperti bersikap ramah dan menerima saran kritik dari anggota, pelayanan yang baik juga harus diberikan kepada non anggota yang juga merupakan calon anggota koperasi, dan memberikan penyuluhan tentang prosedur koperasi syariah.

4. Strategi 7 (S7) yaitu menerapkan sistem reward and punishment untuk anggota dan pengurus yang melanggar. Setiap anggota memiliki tingkat partisipasi dan kontribusi berbeda-beda sehingga diperlukan instrumen tertentu agar nilai-nilai keadilan dapat ditegakan. Nilai keadilan diperlukan untuk menjaga loyalitas anggota karena akan menjadi tidak adil orang yang memiliki kontribusi sedikit tapi mendapatkan banyak dan sebaliknya. Sistem reward diperlukan dalam koperasi BMT. Sistem reward dilakukan dengan memberikan penghargaan pada anggota koperasi yang dalam sistem berkerja sangat baik, dilihat dari kedisiplinan kerja, ketepatan bekerja, konsistensi dalam bekerja. Sedangkan untuk sistem punishment 
dalam koperasi BMT, memberikan sanksi anggota koperasi yang keterlambatan dalam bekerja, ketidakhadiran pekerja tanpa alasan yang jelas. Pemberian punishment diberikan kepada anggota yang sering melanggar. Pemberian punishment berupa teguran, atau memberhentikan sepihak yang tidak sesuai dengan perjanjian kerja.

Tabel 4 Urutan nilai TAS

\begin{tabular}{|c|c|c|}
\hline No & Strategi & Nilai TAS \\
\hline 1 & $\begin{array}{l}\text { Strategi } 3(\mathrm{~S} 3) \text { : } \\
\text { Memperkenalkan macam-macam produk koperasi dikalangan } \\
\text { masyarakat }\end{array}$ & 5,854 \\
\hline 2 & $\begin{array}{l}\text { Strategi } 1 \text { (S1) : } \\
\text { Meningkatkan kualitas sumberdaya manusia yang handal dan } \\
\text { tangguh (berkompeten) }\end{array}$ & 5,754 \\
\hline 3 & $\begin{array}{l}\text { Strategi } 8(\mathrm{~S} 8) \text { : } \\
\text { Meningkatkan kualitas pelayanan dan pengelolaan pada usaha } \\
\text { koperasi sesuai dengan prinsip syariah }\end{array}$ & 5,654 \\
\hline 4 & $\begin{array}{l}\text { Strategi } 7 \text { (S7): } \\
\text { Menerapkan sistem reward and punishment untuk anggota dan } \\
\text { pengurus yang melanggar }\end{array}$ & 5,568 \\
\hline 5 & $\begin{array}{l}\text { Strategi } 9 \text { (S9) : } \\
\text { Menjalin hubungan kemitraan dengan lembaga keuangan yang } \\
\text { sama atau koperasi lain }\end{array}$ & 5,423 \\
\hline 6 & $\begin{array}{l}\text { Strategi } 6(\mathrm{~S} 6) \text { : } \\
\text { Menjalin hubungan komunikasi koperasi dengan pemerintahan } \\
\text { yang terkait }\end{array}$ & 5,414 \\
\hline 7 & $\begin{array}{l}\text { Strategi } 5 \text { (S5) : } \\
\text { Memberikan penyuluhan dalam program-program koperasi yang } \\
\text { jelas dengan membuat SOP }\end{array}$ & 5,382 \\
\hline 8 & $\begin{array}{l}\text { Strategi } 4 \text { (S4) : } \\
\text { Memperbaiki citra koperasi syariah (BMT) dikalangan } \\
\text { masyarakat }\end{array}$ & 5,133 \\
\hline 9 & $\begin{array}{l}\text { Strategi } 10(\mathrm{~S} 10) \text { : } \\
\text { Meningkatkan parsitisipasi kesadaran masyarakat dalam } \\
\text { berkoperasi }\end{array}$ & 4,968 \\
\hline 10 & $\begin{array}{l}\text { Strategi } 2 \text { (S2) : } \\
\text { Memperluas Pangsa Pasar yaitu dengan mempromosikan } \\
\text { koperasi BMT ke masyarakat sekitar }\end{array}$ & 4,888 \\
\hline
\end{tabular}

\section{B. Jangka Menengah (3 - 4 tahun)}

Perencanaan jangkau panjang dipecah-pecah menjadi beberapa pelaksanaan perencanaan jangka menengah, sehingga setiap tahap hendaknya disesuaikan dengan prioritas. Sifat perencanaan ini lebih konkret dan sasaran yang akan dicapai jelas [6].

1. Strategi 9 (S9) yaitu menjalin hubungan kemitraan dengan lembaga keuangan yang sama atau koperasi lain. Kerja sama dengan lembaga lain sangat diperlukan untuk mendapatkan jaringan yang diinginkan sehingga dapat mengembangkan koperasi syariah yang diharapkan nanti.

2. Strategi $6(\mathrm{~S} 6)$ yaitu menjalin hubungan komunikasi koperasi dengan pemerintahan yang terkait. Hubungan komunikasi yang baik memberikan bekal kemampuan manajemen yang baik. Hubungan komunikasi yang baik dengan pemerintah secara 
tidak langsung dapat meningkatan kinerja pengurus dan karyawan karena pemerintahan setempat secara rutin memberikan pelatihan dan pembinaan.

3. Strategi 5 (S5) yaitu memberikan penyuluhan dalam program-program koperasi dengan membuat Standard Operational Procedure (SOP). Menurut hasil wawancara kepada pengurus koperasi, aktivitas teknis yang ada di organisasi tersebut belum memiliki berbagai SOP. Contoh aktivitas teknis yang dimaksud adalah tata cara melakukan suatu kegiatan, mekanisme keanggotaan, prosedur aktivitas karyawan, administrasi, dan keuangan.

\section{Jangka Panjang (5 tahun)}

Rencana jangka panjang menjangkau waktu sekitar 5 tahun kedepan. Perencanaannya berbentuk garis-garis besar yang bersifat sangat strategis dan umum. Perencanaan jangka panjang tidak dapat langsung dipakai sebagai pedoman kerja. Oleh karena itu perlu dijabarkan dalam bentuk perencanaan jangka menengah [6].

1. Strategi Strategi 4 (S4) yaitu memperbaiki citra koperasi syariah BMT dikalangan masyarakat, karena pada saat ini citra koperasi kurang baik sehingga tidak adanya kepedulian masyarakat terhadap koperasi BMT. Citra koperasi sering kali hanya dianggap sebagai badan usaha bukan merupakan suatu sistem sosial ekonomi. Selain itu banyaknya koperasi-koperasi yang dibuat hanya mencari dana-dana proyek pemerintah semakin memperburuk citra koperasi. Hal yang dapat dilakukan dengan cara memberikan penyuluhan terhadap masyarakat tentang Koperasi BMT, mengadakan seminar, ikut serta dalam kegiatan pemerintahan, memberikan brosur-brosur.

2. Strategi 10 (S10) yaitu meningkatkan partisipasi kesadaran masyarakat berkoperasi, karena kesadaran masyarakat sekarang dalam berkoperasi sangat minim sekali. Partisipasi anggota bisa ditingkatkan dengan cara lebih melibatkan anggota dalam pengambilan keputusan maupun rapat-rapat, mengembangkan unit usaha dengan melengkapi dan menambah variasi barang-barang yang dijual sesuai kebutuhan anggota.

3. Strategi 2 (S2) yaitu memperluas Pangsa Pasar yaitu dengan mempromosikan Koperasi BMT ke masyarakat sekitar. Strategi koperasi BMT atau meningkatkan volume penjualan dengan melakukan promosi yaitu membuka unit cabang koperasi, membuat brosur dan iklan.

\section{Simpulan}

Berdasarkan hasil dan pembahasan ditarik kesimpulan dengan membuat usulan strategi antara lain memperbaiki citra koperasi syariah dikalangan masyarakat dengan cara penyuluhan, meningkatkan partisipasi kesadaran masyarakat dalam berkoperasi dengan cara lebih melibatkan anggota dalam pengambilan keputusan maupun rapatrapat, meningkatkan kualitas sumber daya manusia yang handal dan tangguh (berkompeten) dengan memberikan kinerja yang sangat selektif untuk memberikan yang terbaik, dengan memberikan sumber daya yang sudah profesional dalam bidang syariah yang sangat mengenal koperasi lebih jelas lagi. Meningkatkan kualitas pelayanan dan pengelolaan usaha koperasi sesuai dengan prinsip syariah. Menerapkan sistem reward and punishment untuk anggota dan pengurus yang melanggar, menjalin hubungan kemitraan dengan lembaga keuangan yang sama atau koperasi lain, menjalin hubungan komunikasi koperasi dengan pemerintahan, memberikan penyuluhan dalam program-program koperasi dengan membuat SOP, memperkenalkan macam-macam produk koperasi dikalangan masyarakat. Merancang arsitektur strategi yang 
merupakan merupakan tahap awal, yaitu tahap pertama kegiatan pengembangan menuju tahap pengembangan yang berdasarkan rentang waktu selama 1-2 tahun setelah itu, tahap kedua tahap pengembangan bisnis yang berdasarkan rentang waktu selama 3-4 tahun, setelah itu tahapan ketiga yakni mempertahankan usaha Koperasi BMT Syariah Jawa Timur yang berdasarkan rentang waktu 5 tahun, yang sasaran yang akan dilakukan untuk koperasi BMT dapat memperbaiki citra koperasi (syariah), terwujudnya persatuan sesama anggota maupun non anggota, dapat memperkenalkan produk yang lebih baik sebagai respons, dapat mengenalkan koperasi BMT syariah ke masyarakat sekitar, serta dapat memperluas pangsa pasar. Saran yang dilakukan untuk koperasi saat ini yaitu lebih selektif atau lebih hati-hati dalam merumuskan strategi bisnis koperasi BMT yang dijalankan apalagi dengan ketatnya persaingan koperasi saat ini. Penelitian kedepan diharapkan akan mengembangkan atau membandingkan konsep model strategi bisnis Fred David dengan model lainnya seperti model konsep Porter, model konsep Wheelen-Hunger dapat menjadi lebih baik lagi.

\section{Referensi}

[1] D. Harmoyo, "Manajemen Strategi Koperasi Jasa Keuangan Mikro Syariah (KJKS) Studi Kasus di Baitul Mal Wat tamwil (BMT) Syariah Sejahtera Boyolali," MUQTASID Jurnal Ekonomi dan Perbankan Syariah, vol. 3, pp. 299317, 2012.

[2] S. A. Susilo and D. F. Septiarini, "Manajemen Risiko Likuiditas di BMT ABC Jawa Timur," Jurnal Ekonomi Syariah Teori dan Terapan, vol. 2, 2015.

[3] A. Osterwalder and Y. Pigneur, Business model generation: a handbook for visionaries, game changers, and challengers: John Wiley \& Sons, 2010.

[4] A. Sakti, "Pemetaan Kondisi Dan Potensi BMT: Kemitraan dalam rangka Memperluas Pasar \& Jangkauan Pelayanan Bank Syariah kepada Usaha Mikro," Jurnal al-Muzara'ah, vol. 1, 2015.

[5] M. Mikhriani, "Koperasi Dan BMT: Sebuah Fenomena Sumber Dana Untuk Kemaslahatan Umat," Jurnal Dakwah, vol. 12, pp. 33-52, 2011.

[6] F. R. David, Konsep Manajemen Strategis (Terjemahan). Jakarta: Prenhallindo, 2004.

[7] F. Rangkuti, Analisis SWOT Teknik Membedah Kasus Bisnis: Reorientasi, Konsep, dan Strategi untuk Menghadapi Abad 21. Jakarta: PT. Gramedia Pustaka Utama, 2000. 